\title{
LETTER
}

\section{Bi-bearing and REE-free zálesíite from the Fuka mine, Okayama Prefecture, Japan}

\author{
Takahiro TANAKA*, Tetsuo MinAKaWA $^{*}$, Isao KUSACHI $^{* *}$ and Mitsuo TANABE ${ }^{* * *}$ \\ *Department of Mathematics, Physics and Earth Science, Faculty of Science and Engineering, \\ Ehime University, Ehime 790-8577, Japan \\ **509-6 Shiraishi, Okayama 701-0143, Japan \\ ***2058-3 Niimi, Niimi, Okayama 718-0011, Japan
}

\begin{abstract}
Zálesiite is found to exist as hexagonal prismatic crystals (length: up to $1 \mathrm{~mm}$; width: $10 \mu \mathrm{m}$ ) and fibrous aggregates in the alteration zone in crystalline limestone near gehlenite-spurrite skarns at the Fuka mine, Okayama Prefecture, Japan. The mineral is pale green to emerald green in color with a silky to vitreous luster. Andradite, aragonite, bornite, cahnite, chalcocite, chalcopyrite, conichalcite, johnbaumite, and an unidentified $\mathrm{Ca}-\mathrm{Cu}$ arsenate mineral coexist in the abovementioned limestone. From SEM-EDS analysis, the empirical formula of zálesiite is found to be $\left(\mathrm{Ca}_{0.74} \mathrm{Bi}_{0.26}\right)_{\Sigma 1.00}\left(\mathrm{Cu}_{5.80} \mathrm{Ca}_{0.18} \mathrm{Ni}_{0.01} \mathrm{Zn}_{0.01}\right)_{\Sigma 6.00}\left[\left(\mathrm{As}_{2.86} \mathrm{Si}_{0.12} \mathrm{P}_{0.02}\right)_{\Sigma 3.00}\left(\mathrm{O}_{11.14} \mathrm{OH}_{0.86}\right)_{\Sigma 12.00}\right](\mathrm{OH})_{6} \cdot 3 \mathrm{H}_{2} \mathrm{O}$ on the basis of the following calculation: $10(M 1+M 2+X)+6(\mathrm{OH})+3\left(\mathrm{H}_{2} \mathrm{O}\right)$. Zálesíite collected from the Fuka mine contains $\mathrm{Bi}$ and is free of REE. The unit cell parameters of the zálesíite crystals are $a=13.656(9)$, $c=5.850(4) \AA, V=945(1) \AA^{3}$, and $Z=2$. It is inferred that zálesíite is formed by the reaction between crystalline limestone, cahnite, johnbaumite, $\mathrm{Cu}$ sulfide, and a Bi-rich hydrothermal solution.
\end{abstract}

Keywords: Zálesíite, Mixite-group, Bi, Arsenate, Fuka mine, Hydrothermal solution

\section{INTRODUCTION}

Zálesíite, ideally represented as $\mathrm{CaCu}_{6}\left(\mathrm{AsO}_{4}\right)_{2}\left(\mathrm{AsO}_{3} \mathrm{OH}\right)$ $(\mathrm{OH})_{6} \cdot 3 \mathrm{H}_{2} \mathrm{O}$, is a member of the mixite group, whose minerals have the general formula $M 1 M 2_{6}\left(\mathrm{XO}_{4}\right)_{3}(\mathrm{OH})_{6}$. $3 \mathrm{H}_{2} \mathrm{O}$; here, $M 1=\mathrm{Al}, \mathrm{Bi}, \mathrm{Ca}$, rare-earth elements (REE), $M 2=\mathrm{Cu}$, and $X=\mathrm{As}$ or P. In the mixite group elements, charge compensation during the substitution of a divalent cation (e.g., $\mathrm{Ca}^{2+}$ ) with a trivalent cation (e.g., $\mathrm{Y}^{3+}$ ) occurs by the concomitant substitution of $\mathrm{OH}^{-}$by $\mathrm{O}^{2-}$ (Aruga and Nakai, 1985). Zálesíite is the $\mathrm{Ca}$ analog of agardite-(Y) $\left[\mathrm{YCu}_{6}\left(\mathrm{AsO}_{4}\right)_{3}(\mathrm{OH})_{6} \cdot 3 \mathrm{H}_{2} \mathrm{O}\right]$ and mixite $\left[\mathrm{BiCu}_{6}\left(\mathrm{AsO}_{4}\right)_{3}\right.$ $(\mathrm{OH})_{6} \cdot 3 \mathrm{H}_{2} \mathrm{O}$ ]. Zálesíite was first reported from Zálesí, Czech Republic by Sejkora et al. (1999). Subsequently, the mineral was found in the copper deposits at the Dolores prospect, Spain (de Baranda et al., 2003) and the Gold Hill mine, Tooele County, Utah (Adams, 2005). However, the substitution aspect in zálesíite has not yet been studied in sufficient detail.

At the Fuka mine, arsenate minerals such as cahnite (Shiraga et al., 2002) and johnbaumite (Kusachi et al.,

doi:10.2465/jmps.081021c

T. Tanaka, takahiro@sci.ehime-u.ac.jp Corresponding author

T. Minakawa,minagawa@sci.ehime-u.ac.jp
1996) are found to exist in the form of veins cutting through crystalline limestone near gehlenite-spurrite skarns. Zálesíite is found in the alteration zone in crystalline limestone at the fourth level of the Fuka mine. The location of the alteration zone is different from the vein reported by Shiraga et al. (2002) and Kusachi et al. (1996). This is the first report on zálesiite found in Japan. This study deals with the genesis, mode of occurrence, and mineralogical properties of zálesíite found at the Fuka mine.

\section{OCCURRENCE AND PHYSICAL PROPERTIES}

The Fuka mine is located approximately $40 \mathrm{~km}$ westnorth-west of Okayama City, Japan (Lat. 34 $46^{\prime} \mathrm{N}$, Long. $133^{\circ} 26^{\prime} \mathrm{E}$ ). The alteration zone (Fig. 1), which is found in crystalline limestone at the fourth level of the Fuka mine, extends vertically upwards and assumes the shape of the letter L. Cavities occur in the upper and lower portions of the alteration zone. Cahnite and pentahydroborite are present on the walls of these cavities and in the peripheral portion of the cavity in the upper portion. Bornite, chalcocite, chalcopyrite, cuprite, stringhamite, and wittichenite are sporadically disseminated in the crystalline 


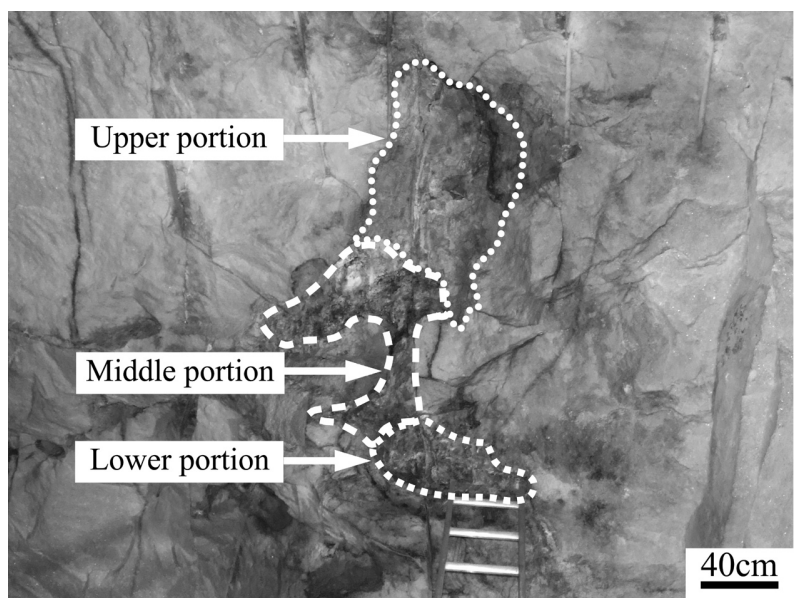

Figure 1. Alteration zone in crystalline limestone at the fourth level of the Fuka mine.

limestone in the middle portion of the alteration zone. Only chalcocite, cuprite, and stringhamite are found in the euhedral crystals of calcite. Andradite, aragonite, bornite, cahnite, chalcocite, chalcopyrite, conichalcite, johnbaumite, zálesíite, and an unidentified $\mathrm{Ca}-\mathrm{Cu}$ arsenate mineral occur in the cavity in the lower portion of the alteration zone. Johnbaumite is detected on the surface of the wall of the cavity. Andradite, bornite, chalcocite, and chalcopyrite are present in jounbaumite and calcite. Andradite also exists in the form of euhedral crystals.

Zálesíite occurs as hexagonal prismatic crystals (length: up to $1 \mathrm{~mm}$; width: $10 \mu \mathrm{m}$ ) and fibrous aggregates (Fig. 2) in the euhedral crystals of calcite, along with conichalcite and the unidentified $\mathrm{Ca}-\mathrm{Cu}$ arsenate mineral. Zálesíite is pale green to emerald green in color with a silky to vitreous luster. Pleochroism is weak, varying from pale green to pale yellowish green. The streaks are whitish to pale green in color. The calculated density of zálesíite at $Z=2$ is $3.58 \mathrm{~g} / \mathrm{cm}^{3}$. Moreover, zálesíite gradually dissolves in dilute hydrochloric acid.

\section{CHEMICAL COMPOSITION}

Chemical analyses of zálesíite were carried out on a scanning electron microscope (JEOL JSM-5400) equipped with an energy-dispersive spectrometer (Oxford ISIS L200) at Ehime University. Quantitative analyses were performed at an accelerating potential of $15 \mathrm{kV}$, beam current of $4.0 \times 10^{-10} \mathrm{~A}$, and a beam diameter of $3 \mu \mathrm{m}$. The standards used were wollastonite (for $\mathrm{Ca}$ and $\mathrm{Si}$ ), InAs (for $\mathrm{As}$ ), $\mathrm{GaP}$ (for $\mathrm{P}$ ), and pure $\mathrm{Bi}, \mathrm{Fe}, \mathrm{Co}, \mathrm{Ni}, \mathrm{Zn}$, and $\mathrm{Cu}$. All the data were corrected using the ZAF matrix-correction program. The averaged chemical compositions of the minerals shown in Table 1 are compared with those reported by Sejkora et al. (1999) and de Baranda et

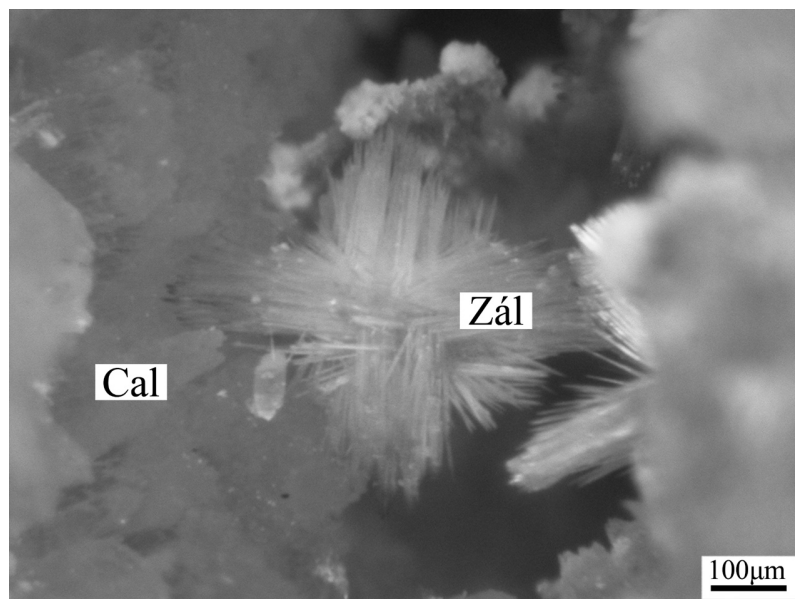

Figure 2. Photograph of zálesíite obtained from the Fuka mine. Abbreviations: Zál, zálesíite; Cal, calcite.

Table 1. Chemical composition of zálesíite

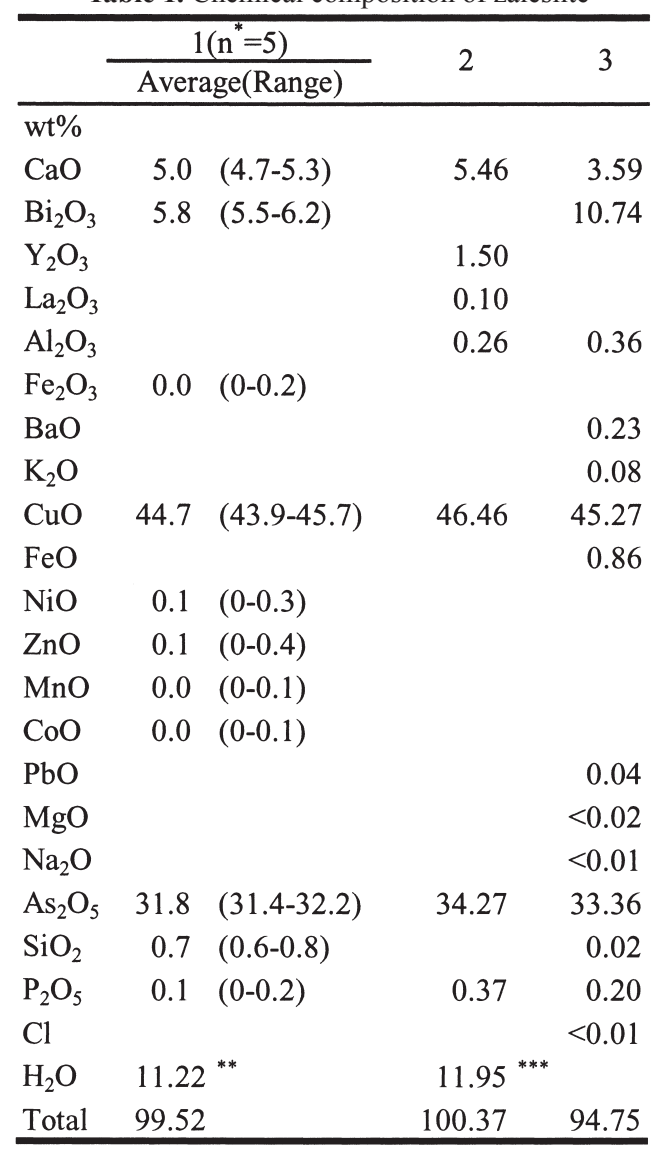

${ }^{*}$ Data corresponding to five analyzed spots.

*** From stoichiometry.

**** Weight loss from TG data.

1. Fuka mine (Present work).

2. Zálesí, Czech Republic (Sejkora et al., 1999).

3. Dolores prospect, Spain (de Baranda et al., 2003). 
Table 2. XRD data obtained for zálesíite

\begin{tabular}{|c|c|c|c|c|c|c|c|c|c|c|c|c|c|c|c|}
\hline \multirow[b]{2}{*}{$h$} & \multirow[b]{2}{*}{$k$} & \multirow[b]{2}{*}{$l$} & \multicolumn{3}{|c|}{1} & \multicolumn{2}{|l|}{2} & \multirow[b]{2}{*}{$h$} & \multirow[b]{2}{*}{$k$} & \multirow[b]{2}{*}{$l$} & \multicolumn{2}{|r|}{1} & \multirow[b]{2}{*}{$I$} & \multicolumn{2}{|l|}{2} \\
\hline & & & $d_{\text {calc. }}$ & $d_{\text {meas. }}$ & $I$ & $d$ & $I$ & & & & $d_{\text {calc. }}$ & $d_{\text {meas }}$ & & $d$ & $I$ \\
\hline 1 & 0 & 0 & 11.83 & 11.79 & 100 & 11.64 & 100 & 6 & 1 & 0 & 1.804 & 1.803 & 3 & 1.7921 & 6 \\
\hline 2 & 0 & 0 & 5.91 & & & 5.856 & 3 & 2 & 1 & 3 & 1.787 & 1.783 & 3 & 1.7734 & 3 \\
\hline 1 & 0 & 1 & 5.24 & 5.28 & 3 & 5.251 & 2 & 2 & 2 & 3 & 1.693 & & & 1.7164 & 2 \\
\hline 1 & 1 & 1 & 4.44 & 4.46 & 18 & 4.431 & 41 & 4 & 4 & 0 & 1.707 & & & 1.6959 & 4 \\
\hline 2 & 0 & 1 & 4.16 & 4.17 & 3 & 4.153 & 1 & 3 & 5 & 0 & 1.689 & & & 1.6787 & 4 \\
\hline 3 & 0 & 0 & 3.942 & 3.929 & 4 & 3.911 & 5 & 4 & 4 & 1 & 1.639 & & & 1.6308 & 4 \\
\hline 1 & 2 & 1 & 3.552 & 3.559 & 20 & 3.541 & 8 & 2 & 5 & 2 & 1.590 & & & 1.6152 & 3 \\
\hline 2 & 2 & 0 & 3.414 & 3.405 & 8 & 3.387 & 17 & 1 & 7 & 0 & 1.566 & & & 1.5862 & 2 \\
\hline 1 & 3 & 0 & 3.280 & 3.272 & 3 & 3.254 & 22 & 1 & 6 & 2 & 1.535 & & & 1.5562 & 4 \\
\hline 2 & 2 & 1 & 2.949 & 2.951 & 17 & 2.9347 & 42 & 0 & 0 & 4 & 1.463 & & & 1.5316 & 2 \\
\hline 3 & 1 & 1 & 2.861 & & & 2.8494 & 4 & 4 & 4 & 2 & 1.474 & & & 1.4703 & 2 \\
\hline 2 & 3 & 0 & 2.713 & 2.709 & 9 & 2.6932 & 29 & 1 & 0 & 4 & 1.452 & 1.451 & 7 & 1.4359 & 5 \\
\hline 1 & 4 & 0 & 2.581 & 2.573 & 9 & 2.5624 & 30 & 2 & 7 & 1 & 1.403 & & & 1.3953 & 1 \\
\hline 3 & 2 & 1 & 2.461 & 2.462 & 23 & 2.4534 & 10 & 3 & 4 & 3 & 1.377 & 1.379 & 7 & 1.3758 & 3 \\
\hline 2 & 2 & 2 & 2.221 & & & 2.2194 & 4 & 5 & 2 & 3 & 1.359 & 1.360 & 7 & 1.3567 & 1 \\
\hline 1 & 3 & 2 & 2.183 & & & 2.1847 & 2 & 2 & 2 & 4 & 1.344 & & & 1.3481 & 2 \\
\hline 3 & 3 & 1 & 2.121 & 2.117 & 3 & 2.1098 & 10 & 1 & 3 & 4 & 1.336 & & & 1.3403 & 1 \\
\hline 4 & 0 & 2 & 2.079 & & & 2.0797 & 1 & 3 & 7 & 0 & 1.331 & & & 1.3225 & 4 \\
\hline 3 & 2 & 2 & 1.989 & & & 1.9886 & 2 & & & & & & & & \\
\hline 6 & 0 & 0 & 1.971 & & & 1.9578 & 2 & & $(\AA)$ & & & $13.656(9)$ & & $13.571(1)$ & \\
\hline 1 & 0 & 3 & 1.924 & & & 1.9315 & 4 & & $(\AA)$ & & & $5.850(4)$ & & $5.880(1)$ & \\
\hline 5 & 0 & 2 & 1.839 & & & 1.8352 & 2 & & $\left(\AA^{3}\right)$ & & & $945(1)$ & & $937.8(2)$ & \\
\hline
\end{tabular}

1. Fuka mine (Present work).

2. Zálesí, Czech Republic (Sejkora et al., 1999).

al. (2003). No REE could be detected in our analyses. The empirical formula of zálesíite obtained from the Fuka mine was found to be $\left(\mathrm{Ca}_{0.74} \mathrm{Bi}_{0.26}\right)_{21.00}\left(\mathrm{Cu}_{5.80} \mathrm{Ca}_{0.18} \mathrm{Ni}_{0.01} \mathrm{Zn}_{0.01}\right)$ ${ }_{\Sigma 6.00}\left[\left(\mathrm{As}_{2.86} \mathrm{Si}_{0.12} \mathrm{P}_{0.02}\right)_{\Sigma 3.00}\left(\mathrm{O}_{11.14} \mathrm{OH}_{0.86}\right)_{\Sigma 12.00}\right](\mathrm{OH})_{6} \cdot 3 \mathrm{H}_{2} \mathrm{O}$ on the basis of the following calculation: $10(M 1+M 2+X)$ $+6(\mathrm{OH})+3\left(\mathrm{H}_{2} \mathrm{O}\right)$. The $\mathrm{H}_{2} \mathrm{O}$ content was estimated by stoichiometry.

\section{CRYSTALLOGRAPHY}

X-ray powder diffraction (XRD) data for zálesíite were recorded on a MAC Science M18XHF-SRA diffractometer at Ehime University using graphite-monochromatized $\mathrm{Cu} K \alpha$ radiation generated at $40 \mathrm{kV}$ and $80 \mathrm{~mA}$. The XRD data are shown in Table 2 and are compared with those of zálesiite obtained from the type locality (Sejkora et al., 1999). The unit cell parameters calculated from the XRD data are $a=13.656(9), c=5.850(4) \AA, V=945(1) \AA^{3}$, and $Z=2$.

\section{DISCUSSION}

Zálesíite from the Fuka mine contains Bi and is free of REE, similar to that obtained from the Dolores prospect (de Baranda et al., 2003). The chemical compositions at large cation sites in zálesíite and Ca-bearing mixite group

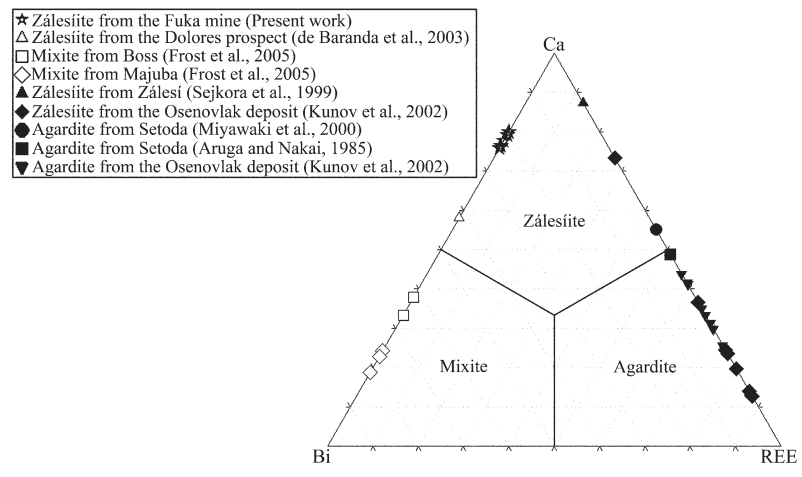

Figure 3. Ca-Bi-REE ternary diagram of the $M$ site in the mixite group minerals.

minerals are plotted on a $\mathrm{Ca}-\mathrm{Bi}-\mathrm{REE}$ ternary diagram (Fig. 3). These minerals can be plotted in two distinct regions. The Agardite-zálesíite solid solutions do not contain Bi. On the other hand, the mixite-zálesíite solid solutions do not contain REE. Thus it is inferred that zálesíite has distinct solid solution properties of the agardite-zálesíite series as well as the mixite-zálesiite series.

The $a$-axis of zálesiite obtained from the Fuka mine is longer than that of zálesíite obtained from the type specimen; in addition, the cell volume of zálesíite from the Fuka mine is larger than that of zálesiite obtained from the type specimen. In zálesiite obtained from the 
type locality, one-fifth of the total $\mathrm{Ca}$ content are substituted by Y, Al, and La. The enlargement of the unit cell in zálesíite obtained from the Fuka mine is thought to be due to the substitution of one-fourth of the $\mathrm{Ca}$ atoms with $\mathrm{Bi}$, which is larger in size than $\mathrm{Ca}, \mathrm{Al}$, and $\mathrm{Y}$.

The mineral assemblages in the upper, middle, and lower portions of the alteration zone at the Fuka mine differ to a considerable extent. B-bearing minerals are mainly present in the upper portion. From their mode of occurrence, it is likely that these minerals are formed by the reaction between a $\mathrm{B}$-rich hydrothermal solution and crystalline limestone. $\mathrm{Cu}$-bearing sulfides are mainly found in the middle portion. From their mode of occurrence, it is likely that these sulfides formed as primary minerals from a $\mathrm{Cu}$-rich hydrothermal solution. Arsenates and conichalcite pseudomorphs after cahnite and chalcocite typically exist in the lower portion of the alteration zone. It is asserted that $\mathrm{Ca}-\mathrm{Cu}$ arsenate minerals are formed later than cahnite. Moreover, conichalcite and the unidentified $\mathrm{Ca}-\mathrm{Cu}$ arsenate mineral contain up to 3.1 wt $\%$ and $16.7 \mathrm{wt} \%$ of $\mathrm{Bi}_{2} \mathrm{O}_{3}$, respectively. However, the alteration zone contains a very low amount of minerals that are Bi sources. A very small amount of wittichenite is present in the form of grains (diameter: $<5 \mu \mathrm{m}$ ) in the middle portion of the alteration zone. These two observations indicate that the hydrothermal solution is the source of $\mathrm{Bi}$. The cavity in the lower portion of the alteration zone is probably formed by the As-rich and Bi-rich hydrothermal solutions trapped in it. Kusachi et al. (1996) reported that johnbaumite from the Fuka mine is associated with arsenopyrite, löllingite, andradite and magnetite, which are formed by the reaction of fluids bearing elements such as As, Fe, and S with limestone. Shiraga et al. (2002) reported that cahnite from the Fuka mine is formed as a secondary mineral by the hydrothermal alteration of johnbaumite. Thus, the following assumptions are made: (1) andradite and johnbaumite are formed as primary minerals by the reaction between an As-rich $\mathrm{Si}$-bearing solution and sulfides-bearing crystalline limestone at lower part of middle portion; (2) cahnite is formed by the hydrothermal alteration of johnbaumite; (3) conichalcite, zálesíite, and the unidentified $\mathrm{Ca}-\mathrm{Cu}$ arsenate mineral are formed by the reaction between crystalline limestone, cahnite, johnbaumite, $\mathrm{Cu}$-bearing sulfides, and a $\mathrm{Bi}$-rich hydrothermal solution; (4) in these minerals, $\mathrm{Ca}$ and $\mathrm{Cu}$ are derived from crystalline limestone and $\mathrm{Cu}$-bearing sulfides, while As is formed from the dissociation of cahnite and johnbaumite; (5) the alteration zone is formed by the reaction of four types of hydrothermal solutions that intruded into crystalline limestone: a B-rich solution, a $\mathrm{Cu}$-rich solution, an $\mathrm{As}$-rich $\mathrm{Si}$-bearing solution, and a $\mathrm{Bi}$-rich solution.

\section{ACKNOWLEGMENTS}

We would like to thank Bihoku Funka Kogyo Co., Ltd. and Mr. K. Tanabe for assistance in the field work.

\section{REFERENCES}

Adams, P.M. (2005) Zálesíite from the Gold Hill mine, Toole County, Utah. Mineral News, 21, (8) August, 1, 3, 5.

Aruga, A. and Nakai, I. (1985) Structure of Ca-rich agardite, $\left(\mathrm{Ca}_{0.40} \mathrm{Y}_{0.31} \mathrm{Fe}_{0.09} \mathrm{Ce}_{0.06} \mathrm{La}_{0.04} \mathrm{Nd}_{0.01}\right) \mathrm{Cu}_{6.19}\left[\left(\mathrm{AsO}_{4}\right)_{2.42}\left(\mathrm{HAsO}_{4}\right)_{0.49}\right]$ $(\mathrm{OH})_{6.38} \cdot 3 \mathrm{H}_{2} \mathrm{O}$. Acta Crystallographioca, C41, 161-163.

de Baranda, B.S., del Tánago, J.G. and Viñals, J. (2003) Secondary minerals of the Mazarrón-Águilas mining district, Murcia Province, Spain. The Mineralogical Record, 34, 315-334.

Frost, R.L., Weier, M., Martens, W. and Duong, L. (2005) Identification of mixite minerals an SEM and Raman spectroscopic analysis. Mineralogical Magazine, 69, 169-177.

Kunov, A.Y., Nakov, R.A. and Stanchev, C.D. (2002) First agardite-(Y), $-(\mathrm{Nd}),-(\mathrm{La})$ find in Bulgaria. Neues Jahrbuch für Mineralogie, Monatshefte, 107-116.

Kusachi, I., Henmi, C. and Kobayashi, S. (1996) Johnbaumite from Fuka, Okayama Prefecture, Japan. Mineralogical Journal, 18, 60-66.

Miyawaki, R., Matsubara, S., Yokoyama, K., Kato, A. and Imai, H (2000) Agardite-(Y) and associated copper minerals from Setoda, Hiroshima Prefecture, Japan. Memories of the National Science Museum, Tokyo, 32, 19-38.

Sejkora, J., Řídkošil, T. and Šrein, V. (1999) Zálesíite, a new mineral of the mixite group, from Zálesí, Rychledské hory Mts., Czech Republic. Neues Jahrbuch für Mineralogie, Abhandlungen, 175, 105-124.

Shiraga, K., Kusachi, I., Kobayashi, S. and Takechi, Y. (2002) Cahnite from Fuka, Okayama Prefecture, Japan. Journal of Mineralogical and Petrological Sciences, 97, 70-73.

Manuscript received October 21, 2008

Manuscript accepted January 12, 2009

Published online April 10, 2009

Manuscript handled by Norimasa Shimobayashi 